\title{
PENTINGNYA PENDIDIKAN KARAKTER DALAM KELUARGA BAGI PERKEMBANGAN KEPRIBADIAN ANAK
}

Anik Indramawan, M.Pd.

anikindramawan@iaipd-nganjuk.ac.id

\begin{abstract}
ABSTRAK
Orang tua wajib mengajarkan akhlak yang mulia kepada anak sebagai dasar kepribadian. Orang tua harus mampu menjadi tauladan dan contoh atau model yang bisa ditiru oleh anak dalam keluarga. Keluarga memberi peran yang sangat besar dalam pendidikan karakter karena waktu anak banyak berada di rumah. Keluarga menjadi pendidik karakter anak yang pertama sebelum dia mendapatkan pendidikan di sekolah. Orang tua terutama ibu memiliki peran yang tak dapat dipungkiri, fungsi ibu sebagai pendidik di lingkungan keluarga tidak dapat tergantikan, ibu lah yang mengandung, melahirkan, menyusui anaknya. Karena itulah ibu disebut sebagai sekolah pertama dan utama bagi anak. Tidak hanya ibu, bapak juga punya tanggung jawab dalam mendidik anak. Faktor terpenting dalam menentukan keberhasilan kehidupan anak anak diantaranya adalah usaha orang tua. Karena itu, orang tua harus berusaha menciptakan suasana serta keadaan yang menentramkan bagi anak anaknya. Memberikan waktu yang menyenangkan tidak hanya untuk tinggal di rumah tapi juga melakukan proses belajar yang penuh semangat pada anak anak yaitu dengan cara menggunakan beberapa strategi. Karena keberhasilan pendidikan anak, sangat bergantung pada pertanggungjawaban orang tua dalam melaksanakan tugasnya. Peran orang tua sebagai penyemangat dalam membentuk karakter anak di rumah menjadi sebuah strategi dalam menciptakan proses belajar yang bisa menggugah anak menjadi aktif sehingga anak mendapatkan pembelajaran sikap dan tingkah laku yang akan terus berkembang. Pendidikan karakter yang diterapkan sejak dini dari keluarga akan menjadi dasar bagi anak dalam perkembangan selanjutnya. Keluarga juga merupakan institusi atau lembaga pertama tempat anak menerima pendidikan dan merupakan wahana tempat tumbuh dan terbentuknya sifatsifat kepribadian anak.
\end{abstract}

Kata kunci: Pendidikan karakter, keluarga, kepribadian anak

\section{PENDAHULUAN}

Pendidikan karakter tidak cukup hanya dengan memberikan pengetahuan tentang adanya nilai-nilai karakter namun juga melibatkan perasaan sehingga mampu untuk membedakan baik buruk sebuah nilai yang akan menentukan tindakan apa yang akan diambil dan akhirnya diwujudkan dalam tindakan dan perbuatan yang sesuai dengan nilai-nilai yang dianutnya setelah melalui proses pengetahuan hingga merasuk ke dalam perasaan.

Pendidikan karakter dinilai sangat penting untuk ditanamkan pada anak sedini mungkin karena akan memudahkan untuk membentuk karakternya. Sekolah, keluarga 
maupun lingkungan seharusnya lebih banyak memberikan porsi yang cukup untuk perkembangan kepribadian. Semakin banyak ilmu yang di dapat dari sekolah maupun keluarga, semakin baik pula perkembangan kepribadiannya. Lingkungan sekolah dan keluarga merupakan sarana yang strategis untuk melaksanakan pendidikan karakter karena sebagian besar anak menghabiskan waktunya di sekolah dan rumah sehingga apa yang diperolehnya akan mempengaruhi pembentukan karakternya. Peran guru dan orangtua sangat penting dalam proses pendidikan anak. Seperti yang kita ketahui bahwa terdapat beberapa faktor yang sangat mendukung dan menentukan keberhasilan suatu proses belajar yaitu antara lain orang tua, guru, anak, juga sarana dan prasarana pendidikan serta yang tidak kalah pentingnya adalah lingkungan, baik lingkungan keluarga, lingkungan sekolah dan lingkungan masyarakat dimana siswa melakukan interaksi sosial setiap hari.

Pada dasarnya perkembangan anak tidak hanya dipengaruhi oleh faktor pembawaan sejak lahir semata, tetapi juga dipengaruhi oleh faktor lain seperti lingkungan pendidikan. Hal ini berarti pada masa depan kehidupan manusia, tidak terkecuali pada anak, bergantung pada potensi pembawaan yang mereka warisi dari orang tua pada proses pematangan, dan proses pendidikan yang mereka alami. Seberapa jauh perbedaan pengaruh antara pembawaaan dengan lingkungan, bergantung pada besar kecilnya efek lingkungan yang dialami siswa. Lingkungan yang dapat kita jadikan sebagai sumber belajar banyak sekali, diantaranya lingkungan keluarga, alam, masyarakat, sekolah dan lain-lain. Berdasarkan hal tersebut dapat dipahami, bahwa salah satu fungsi rumah adalah sebagai tempat tinggal keluarga. Anak dalam perspektif Islam merupakan amanah dari Allah SWT. Dengan demikian, semua orang tua berkewajiban untuk mendidik anaknya agar dapat menjadi insan yang shaleh, berilmu, dan bertaqwa. Keluarga dianggap sebagai tempat berkembangnya individu, di mana keluarga ini merupakan sumber utama dari sekian banyak sumber pendidikan. Keluarga juga dinilai sebagai lapangan pertama, di mana di dalamnya seorang anak akan menemukan pengaruhpengaruh dan unsur-unsur kebudayaan yang berlaku di masyarakatnya. Hal itu terbukti dalam menentukan pentingnya peran keluarga pada fase pertama kanak-kanak betul-betul sangat menentukan proses perkembangan pada fase-fase berikutnya. 


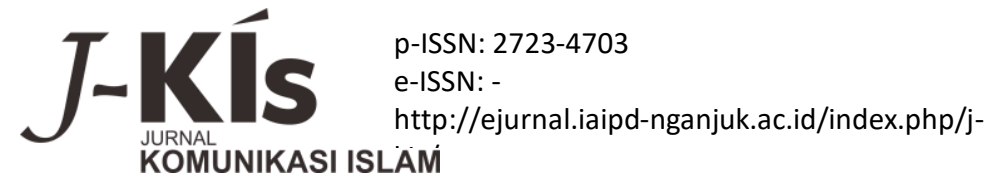

\section{PEMBAHASAN}

\section{Pengertian pendidikan karakter}

Karakter dimaknai sebagai cara dan perilaku yang khas tiap individu untuk hidup dan bekerja sama, baik dalam lingkungan keluarga, masyarakat, bangsa dan negara. Pendidikan karakter memiliki peran penting untung membangun karakter seseorang. Pendidikan karakter adalah sebuah sistem yang menanamkan nilai-nilai karakter pada peserta didik, yang mengandung komponen pengetahuan, kesadaran individu, tekad serta adanya kemauan dan tindakan untuk melaksanakan nilai-nilai yang baik terhadap Tuhan Yang Maha Esa, sesama manusia, lingkungan, maupun bangsa sehingga akan terwujud insan kamil. Pengertian karakter dalam kamus besar Bahasa Indonesia adalah sifat-sifat kejiwaan, akhlak atau budi pekerti yang membedakan seseorang dengan yang lain, atau bermakna bawaan, hati, jiwa, kepribadian, budi pekerti, perilaku, personalitas, sifat, tabiat, tempramen, watak. karakter mengacu kepada serangkaian sikap (attitudes), perilaku (behaviors), dan motivasi (motivations), dan keterampilan (skill). Karakter adalah watak, sifat, atau hal-hal yang memang sangat mendasar yang ada pada diri seseorang. Hal-hal yang sangat abstrak yang ada dalam diri seseorang. Sering orang menyebutnya dengan tabiat atau perangai. Adanya kesamaan diantara karakter dan watak memang karena kedua-duanya merupakan sifat dasar (asli) yang ada dalam diri individu. Karakter dimaknai sebagai cara dan perilaku yang khas tiap individu untuk hidup dan bekerja sama, baik dalam lingkungan keluarga, masyrakat, bangsa dan negara. Individu yang berkarakter baik adalah individu yang dapat membuat keputusan dan mempunyai sikap mempertanggungjawabkan setiap akibat dari keputusannya. Pendidikan keluarga memegang peranan yang sangat penting dan strategis dalam keberhasilan pendidikan seorang anak. Namun bukan berarti kemudian memandang pendidikan di sekolah dan masyarakat tidak penting. Keberhasilan dalam pendidikan anak tidak dapat dipisahkan dari pengaruh yang seimbang antara pendidikan keluarga, sekolah dan masyarakat.

\section{Pilar-pilar pendidikan karakter}

\section{a. Moral knowing}

William Kilpatrick dalam abdul Majid meyebutkan salah satu penyebab ketidakmampuan seseorang berlaku baik meskipun ia telah memiliki pengentahuan tentang kebaikan itu ( 
moral knowing) adalah karena ia tidak terlatih untuk melakukan kebaikan (moral doing).Berangkat dari pemikiran ini maka kesuksesan pendidikan karaker sangat bergantung pada ada tidaknya knowing, loving, dan doing atau acting dalam penyelenggaraan pendidikan karakter. Moral knowing sebagai aspek pertama memiliki enam unsur, yaitu: kesadaran moral, pengetahuan tentang nilai-nilai moral, penentuan sudut pandang, logika moral,keberanian mengambil menetukan sikap, pengendalian diri.

\section{b. Moral Loving atau Moral Feeling}

Moral Loving merupakan penguatan aspek emosi siswa untuk menjadi manusia berkarakter. Penguatan ini berkaitan dengan bentuk-bentuk sikap yang dirasakan oleh siswa, yaitu kesadaran akan jati diri, yaitu: Percaya diri, kepekaan terhadap derita orang lain, cinta kebenaran, pengendalian diri, kerendahan hati.

\section{c. Moral Doing/Acting}

Setelah dua aspek tadi terwujud, maka moral acting sebagai outcome akan dengan mudah muncul dari para siswa. Namun karakter adalah tabiat yang langsung disetir dari otak, maka ketiga tahapan tadi perlu disuguhkan kepada siswa melalui cara-cara yang logis, rasional, dan demokratis. Sehingga perilaku yang muncul benar-benar sebuah karakter bukan topeng.

\section{Nilai-nilai Karakter}

Nilai-nilai yang dikembangkan dalam pendidikan karakter di Indonesia berasal dari 4 sumber yakni Agama, Pancasila, Budaya, dan Tujuan Pendidikan Nasional. Berdasarkan keempat sumber nilai tersebut, teridentifikasi sejumlah nilai untuk pendidikan karakter sebagai berikut:

\section{1) Religius}

Nilai religius merupakan nilai pembentuk karakter yang sangat penting. Manusia berkarakter adalah manusia yang religius. Memang, ada banyak pendapat tentang relasi antara religius dengan agama. Pendapat yang umum mennyatakan bahwa religius tidak selalu sama dengan agama. Hal ini didasarkan pada pemikiran bahwa tidak sedikit orang beragama tapi tidak menjalankan ajaran secara baik. Mereka bisadisebut beragama, tetapi tidak atau kurang religius. Sementara itu, ada juga seseorang yang perilakunya sangat religius, tetapi kurang memperdulikan ajaran agama. Nilai religius menjadi tujuan utama dari pelaksanaan ziarah kubur tersebut.

2) Jujur

Secara harfiah jujur berarti lurus hati, tidak berbohong, dan tidak curang. Jujur merupakan nilai penting yang harus dimiliki setiap orang. Jujur tidak hanya diucapkan, tetapi juga harus 
tercermin dalam perilaku sehari-hari. Karena sikap jujur akan membawa manusia kea rah yang benar atau kebatilan.

3) Toleransi

Dalam kehidupan yang memiliki keragaman tinggi seperti di Indonesia, toleransi merupakan sikap yang sangat penting. Toleransi berarti sikap membiarkan ketidaksepakatan, dantidak menolak pendapat, sikap dan gaya hidup sendiri.

4) Disiplin

Disiplin adalah kepatuhan untuk menghormati dan melaksanakan suatu sistem yang mengharuskan orang utnuk tunduk patuh kepada keputusan, perintah dan peraturan yang berlaku. Dengan kata lain disiplin adalah sikap menaati peraturan dan ketentuan yang telah ditetapkan tanpa pamrih. Dan mengaplikasikan nilai-nilai kedisiplinan dalam kehidupan sehari-hari untuk membangun kualitas kehidupan masyarakat yang lebih baik.

5) Kerja keras

Tidak ada keberhasilan yang bias dicapai tanpa kerja keras. Kerja keras melambangkan kegigihan dan keseriusan mewujudkan cita-cita. Kerja keras inipenting sekali ditengah budaya instan yang semakin mewabah dalam berbagai bidang kehidupan. Harus ditanamkan penanaman dan kesadaran dikalangan generasi muda bahwa tidak ada orang yang mendapatkan apa yang dicita-citakan tanpa kerja keras. Dengan bekerja keras apapun yang diinginkan semaksimal mungkin bisa terwujud.

6) Kreatif

Kreatif sebagai salah satu nilai character building sangat tepat karena kreatif akan menjadikan seseorang tidakpasif. Jiwanya selalu gelisah (dalam makna positif), pikirannya terus berkembang dan selalu melakukan kegiatan dalam kerangka pencarian hal-hal baru yang bermanfaat bagi kehidupan secara luas.

7) Mandiri

Kemandirian tidak otomatis tumbuh dalam diri seorang anak, mandiri pada dasarnya merupakan hasi dari proses pembelajaran yang berlangsung lama. Mandiri tidak selalu berkaitan dengan usia, bias saja seorang anak sudah memiliki sifat mandiri karena proses latihan atau karena faktor kehidupan yang memaksanya untuk menjadi mandiri. Mandiri merupakan sikap yang harus dimiliki oleh setiap orang yang berguna apabila dala kondisi sendiri dan dalam mengambil keputusan. 
8) Demokratis

Dalam konteks character building, ada beberapa prinsip yang dapat dikembangkan untuk menumbuhkembangkan spirit demokrasi. Pertama, menghormati pendapat orang lain, artinya memberikan hak yang sama kepada orang lain untuk berpendapat sesuai dengan kharakteristik dan kualifikasi pemahamannya sendiri.

Kedua, berbaik sangka terhadap pendapat orang lain. Jika sejak awal memiliki pendapat yang buruk terhadap orang lain, maka apapun yang dikatakannya akan selalu dilihat sebagai hal yang tidak benar. Ketiga, sikap fair terhadap pendapat orang lain. Sikap ini merupakan bagian dari kerangka operasional toleransi dalam perbedaan pendapat.

9) Rasa ingin tahu

Manusia memiliki sifat serba ingin tahu sejak awal kehidupannya. Rasa ingin tahu yang membuat anak bertambah pengetahuannya. Para ahli pendidikan umumnya sepakat bahwa salah satu cirri anak cerdas adalah memiliki rasa ingin tahu yang sangat besar.

10) Semangat kebangsaan

Semangat kebangsaan penting menjadi menjadi nilai pembentuk karakter karena meneguhkan arti dan makna penting sebagai warga negara. Hidup ditengah era globalisasi, persaingan antar bangsa bersifat ketat. Secara praktis, ada 3 langkah untuk meningkatkan semangat kebangsaan. Pertama, mempertingi tingkat pendidikan sehingga mampu mem-filter informasi terhadap kebudayaan asing. Kedua, mengumpulkan informasi sebanyak mungkin tentang budaya dunia agar lebih arif dalam menerima informasi. Ketiga, mempertebal iman dan pengalaman agama. Dalam kehidupan bernegara tentu semangat kebangsaan harus ditanamkan sejak dini untuk bekal dimasa dewasa.

11) Cinta tanah air

Sekarang ini, keputuhan terhadap semangat mencintai tanah air seharusnya semakin ditumbuhkembangkan ditengah gempuran globalisasi yang semakin tidak terkendali. Cinta tanah air tidak hanya merefleksikan kepemilikan, tetapi juga bagaimana mengangkat harkat dan martabat bangsa ini dalam kompetisi global.

12) Menghargai prestasi

Dalam iklim kehidupan sekarang ini, arus kompetisi kian ketat. Dalam konteks pengembangan karakter, penting untuk menanamkan menghargai prestasi kepada anak-anak.

13) Bersahabat 
Dalam pembangunan karakter, bersahabat harus mendapatkan perhatian yang serius. Jangan sampai anak-anak tumbuh menjadi manusia arogan, sok dan tidak menghargai yang lainnya. Manusia membutuhkan kehadiran orang lain secara tulus. Memang tidak mungkin semua relasi dibangun berdasarkan ketulusan, tetapi dalam kehidupan ini, relasi berbasis ketulusan menjadi bagian yang tidak boleh diabaikan.

14) Cinta damai

Permusuhan lebih cepat berkembang karena isu-isu yang melibatkan suara. Penyimpangan informasi yang disebabkan salah dengar atau salah arti menghasilkan kesimpulan dan reaksi yang berbeda. Kesalahan yang seperti itulah pemicu pertikaian antar sesama. Budaya damai harus terus ditumbuhkembangkan di berbagai aspek kehidupan. Kekerasan dalam berbagai bentuknya sekarang ini semakin banyak ditemukan. Harus ada kemauan dari berbagai pihak untuk membangun secara sistemis cinta damai menjadi budaya yang mengakar dalam kehidupan.

\section{5) Gemar membaca}

Manusia berkarakter adalahyang selalu gigih mencari pengetahuan. Ada banyak cara mendapatkan pengetahuan, salah satunya dengan kegiatan membaca. Lewat membaca, karakter seseorang akan semakin arif karena merasa bahwa pengetahuannya selalu kurang. Selalu ada banyak hal yang belum dikuasai sehingga tidak menjadikan orang sombong.

16) Pantang menyerah

Kemajuan sebuah bangsa hanya bisa diperoleh jika masyarakatnya tahan banting, kerja keras, tidak menyerah, tekun, berulang kali gagal tapi tidak patah semangat, dan selalu menemukan hal-hal baru yang bermanfaat.

17) Peduli lingkungan

Manusia merupakan makhluk sosial. Ia hidup dan menjadi bagian tidak terpisah dari lingkungannya. Karenanya, manusia tidak bisa sepenuhnya egois dan beranggapan kalau dirinya bisa hidup sendiri tanpa peran serta orang lain.

18) Peduli sesama

Berkaitan dengan hal ini, penting merenungkan pendapat filsuf Deepak Chopra sebagaimana dikutip oleh Ngainum Naim, beliau mengatakan " Kalau kamu melayani sesama, kamu mendapatkan balasan yang lebih banyak. Kalau kamu memberikan hal yang baik, hal yang baik akan mengalir kepadamu." 
Peduli sesama harus dilakukan tanpa pamrih, tanpa pamrih berani tidak mengharapkan balasan atas pemberian atau bentuk apapun yang kita lakukan kepada orang lain. Jadi saat melakukan aktivitas sebagai bentuk kepedulian, tidak ada keengganan atau ucapan menggerutu. Semuanya dilakukan dengan cuma-cuma, tanpa pamrih, hati terbuka dan tanpa menghitung-hitung, kepedulian itu tidak bersyarat.

\section{Faktor-faktor yang Mempengaruhi Pendidikan Karakter}

Faktor yang mempengaruhi pendidikan karakter digolongkan ke dalam 2 bagian, yaitu faktor intern dan faktor ekstern. Adapun faktor intern (berasal dari dalam) yang pertama Insting atau naluri, insting adalah suatu sifat yang dapat menumbuhkan perbuatan yang menyampaikan pada tujuan dengan berfikir lebih dahulu ke arah tujuan itu dan tidak didahului latihan perbuatan itu. Kedua, Adat atau kebiasaan, merupakan salah satu faktor penting dalam tingkah laku manusia karena sikap dan perilakunya yang menjadi karakter atau akhlak sangat erat sekali dengan kebiasaan, kebiasaan adalah perbuatan yang selalu diulang-ulang sehingga mudah untuk dikerjakan. Ketiga, Kehendak/kemauan, kehendak adalah kemauan untuk melangsungkan segala ide dan segala yang dimaksud, alaupun disertai dengan berbagai rintangan dengan kesukaran dan kesulitan.

Keempat, Suara batin atau suara hati, dalam diri manusia terdapat suatu kekuatan yang sewaktu-waktu memberikan peringatan (isyarat) jika tingkah laku manusia berada di ambang bahaya atau keburukan. Kelima, keturunan, merupakan suatu faktor yang dapat mempengaruhi perbuatan manusia. Ada dua macam sifat sesuai dengan garis keturunannya, yaitu sifat jasmaniyah dan sifat ruhaniyah.

Adapun faktor ekstern (bersifat dari luar) yang mempengaruhi pendidikan karakter yakni pertama, Pendidikan. Pendidikan adalah usaha untuk meningkatkan diri dalam segala aspeknya dan mempunyai pengaruh yang sangat besar dalam pembentukan karakter. Pendidikan agama perlu dimanifestasikan memalui berbagai media baik pendidikan formal di sekolah, informal di lingkungan keluarga dan pendidikan non-formal yang ada di lingkungan masyarakat. Kedua, Lingkungan. Lingkungan merupakan suatu yang melingkupi suatu tubuh yang hidup, seperti tumbuhan, tanah, udara, dan pergaulan manusia. Manusia hidup selalu berhubungan dengan manusia lainnya dan dengan alam disekitarnya. Adapun lingkungan dibagi kedalam 2 bagian yaitu lingkungan yang bersifat kebendaan dan lingkungan pergaulan yang bersifat kerohanian. Lingkungan yang bersifat kebendaan, lingkungan ala mini dapat mematangkan pertumbuhan bakat yang dibawa seseorang. Lingkungan pergaulan yang bersifat kerohanian, seseorang dapat membentuk kepribadian seseorang menjadi baik begitu 
pula sebaliknya yang hidup di lingkungan yang baik secara langsung atau tidak langsung dapat membentuk kepribadian seeorang menjadi baik begitu pula sebaliknya.

Para orang tua khususnya ibu dapat mempengaruhi kepribadian anak-anak secara signifikan melalui berbagai macam hal yang mereka lakukan maupun hal yang tidak mereka lakukan. Ada tiga aspek hubungan orangtua dan anak yang tampaknya paling berpengaruh, antara lain: kelekatan, pola asuh, dan salah asuh atau pemberian perlakuan yang tidak tepat (maltreatment) terhadap anak.

\section{Model Pendidikan Karakter}

Pendidikan karakter dapat dilakukan dengan berbagai model, diantaranya melalui pembiasaan, keteladanan, dan pembinaan disiplin.

Pembiasaan adalah sesuatu yang sengaja dilakukan secara berulang-ulang agar sesuatu itu dapat menjadi kebiasaan. Pembiasaan sebenarnya berintikan pengalaman, yang dibiasakan itu adalah sesuatu yang diamalkan. Pembiasaan menempatkan manusia sebagai sesuatu yang istimewa, yang dapat menghemat kekuatan, karena akan menjadi kebiasaan yang melekat dan spontan, agar kekuatan itu dapat dipergunakan untuk berbagai kegiatan dalam setiap pekerjaan dan aktivitas lainnya.

Orang tua memiliki andil yang sangat besar terhadap keberhasilan pendidikan, terutama dalam pendidikan karakter yang sangat berperan dalam membentuk pribadi anak. Dalam pendidikan karakter pribadi orang tua akan menjadi teladan, diteladani, atau keteladanan bagi anak. Pembinaan disiplin

Dalam rangka menyukseskan pendidikan karakter, orang tua harus mampu menumbuhkan disiplin anak. Diantara pembiasaan yang bisa dilakukan di rumah adalah disiplin dan mematuhi peraturan keluarga, terbiasa senyum ramah pada orang, dan kebiasaankebiasaan lain yang menjadi aktivitas sehari-hari.

\section{Kesimpulan}

Pendidikan karakter pada intinya bertujuan membentuk bangsa yang tangguh, kompetitif, berakhlak mulia, bermoral, bertoleransi, bergotong royong, berjiwa patriotik, berkembang dinamis, berorientasi ilmu pengetahuan dan teknologi yang semuanya dijiwai oleh iman dan takwa kepada Tuhan Yang Maha Esa berdasarkan Pancasila. Pendidikan karakter memiliki peran penting dalam membangun kepribadian seseorang. Orang tua adalah sosok life model yang akan selalu diobservasi dan ditiru oleh anak. Jadi cara yang paling efektif dalam memberikan pendidikan kepada anak adalah ketika orang tua bisa menjadi 
contoh dan teladan yang baik. Ketika ibu mendidik anak untuk sholat, orang tua lebih dulu bisa menjadi contoh bagi anak dengan melakukan sholat. Begitu pula ketika orang tua mendidik anak agar bisa sabar, syukur, senang belajar dan lain sebagainya, cara yang paling efektif adalah ketika ibu bisa menjadi contoh dan mengajak anak untuk melakukannya dengan pendekatan yang penuh cinta dan kasih sayang. Dengan kata lain keberhasilan dan kegagalan orang tua dilihat dari keberhasilan dan kegagalan anak-anaknya. Pendidikan anak oleh orang tua sejak dalam kandungan akan sangat mempengaruhi perkembangan watak atau kepribadian anak, dimana watak dan karakter ini akan mempengaruhi proses perkembangan hidup mereka, baik di dalam masyarakat maupun dalam dunia kerja.

\section{DAFTAR PUSTAKA}

Agustin, Risa. Kamus Lengkap Bahasa Indonesia, Serba Jaya, Surabaya, tt.

Alwisol.Psikologi Kepribadian Edisi Revisi. Malang: UMM Press, 2011.

Berkowitz, Marvin W. \& Bier, Melinda C. 2005. "What works in character education: A research driven guide for educator. http://www.hiho.ne.jp/taku77

Desmita.PsikologiPerkembanganPesertaDidik.Bandung: RemajaRosdakarya, 2012.

Hasibuan, JJ. 2004, ProsesBelajarMengajar, Bandung, Remadja

Jahja,Yudrik.Psikologi Perkembangan. Jakarta: Kencana, 2011.

Kementerian Pendidikan Nasional.2010. Pengembangan Pendidikan Budaya dan Karakter Bangsa: Pedoman Sekolah. Jakarta: Kementerian Pendidikan Nasional.

Khaerudin.http://www.ilmupendidikan.net/2010/03/09/membangun-komunikasi-educatifyang-efektif-dengan-anak-bagi-wanita-karir.php, di unduh pada 15 Januari 2013.

Madan, Yusuf.Sex Education for Children.Terj. IjaSuntana.dalam Mahmud, PsikologiPendidikan. Bandung: PustakaSetia, 2010.

Mahmud, PsikologiPendidikan.Bandung: PustakaSetia, 2010.

Muhadjir,Noeng.MetodologiPenelitian.Yogyakarta: Rake Sarasin, 2011.

Poerwadarminto,

WJS. diolahkembaliolehPusatPembinaandanPengembanganBahasaDepartemenPendidikand anKebudayaan, KamusUmumBahasaIndonesia.Jakarta: PN BalaiPustaka, 1976.

Sudjana,Nana. 2004, Dasar-DasarProsesBelajarMengajar,Bandung, Sinar BaruAlgensindo. 
KOMUNIKASI ISLAMMi

Volume 01, Nomor 01 Juni 2020

Yusuf,Syamsu. Psikologi Perkembangan Anak \& Remaja. Bandung: Remaja Rosdakarya, 2010 